NBER WORKING PAPER SERIES

\title{
DO EMPLOYEE SPINOFFS LEARN MARKETS FROM THEIR PARENTS? EVIDENCE FROM INTERNATIONAL TRADE
}

\author{
Marc-Andreas Muendler \\ James E. Rauch \\ Working Paper 24302 \\ http://www.nber.org/papers/w24302 \\ NATIONAL BUREAU OF ECONOMIC RESEARCH \\ 1050 Massachusetts Avenue \\ Cambridge, MA 02138 \\ February 2018, Revised March 2018
}

We thank Ayal Chen-Zion, Ying Feng, and Kye Lippold for outstanding research assistance. We also thank participants in the USC International Economics Workshop, the APJAE Symposium on Industrial Organization and Global Value Chains, and the 22nd Annual Empirical Investigations in International Trade for many helpful comments. We are responsible for any errors. The views expressed herein are those of the authors and do not necessarily reflect the views of the National Bureau of Economic Research. An Online Supplement is available at http:// econweb.ucsd.edu/ jrauch/pdfs/spinlearn-suppl.pdf

NBER working papers are circulated for discussion and comment purposes. They have not been peer-reviewed or been subject to the review by the NBER Board of Directors that accompanies official NBER publications.

(C) 2018 by Marc-Andreas Muendler and James E. Rauch. All rights reserved. Short sections of text, not to exceed two paragraphs, may be quoted without explicit permission provided that full credit, including $\odot$ notice, is given to the source. 
Do Employee Spinoffs Learn Markets From Their Parents?

Evidence From International Trade

Marc-Andreas Muendler and James E. Rauch

NBER Working Paper No. 24302

February 2018, Revised March 2018

JEL No. F14,L25,L26

\begin{abstract}
$\underline{\text { ABSTRACT }}$
It is well established that employee spinoffs learn their parents' technologies, but little is known about their demand-side learning. We exploit the identification in international trade data of parent markets (countries) to investigate whether exporting employee spinoffs of exporting parents have an advantage in accessing their parents' markets over exporting comparison firms well positioned to learn those markets at arm's length. We find that, controlling for the greater overlap of spinoffs with their parents' export products, at entry spinoffs access 51 percent more parent markets than exporting firms in the same 4-digit industries and municipalities as the parents. This advantage shrinks monotonically with time, becoming statistically insignificant four years after entry, indicating that intrafirm learning provides spinoffs with a four-year head start over learning at arm's length. Spinoffs do not overlap more than comparison firms with parent markets that the parents did not serve at spinoff entry, providing evidence against the alternative hypothesis that product overlap inadequately controls for greater technological similarity of spinoffs to parents. Firm entry into parent markets predicted by spinoff status does not lead to entry into "adjacent" markets the following year.
\end{abstract}

Marc-Andreas Muendler

Department of Economics, 0508

University of California, San Diego

9500 Gilman Drive

La Jolla, CA 92093-0508

and NBER

muendler@ucsd.edu

James E. Rauch

Department of Economics

University of California, San Diego

La Jolla, CA 92093-0508

and NBER

jrauch@ucsd.edu 


\section{Introduction}

Employee spinoffs are widely recognized to be a major mode of entrepreneurship in high-tech manufacturing (Klepper and Sleeper 2005, Franco and Filson 2006). Recognition of their importance in the rest of the economy has been growing (Phillips 2002, Eriksson and Kuhn 2006, Hvide 2009, Muendler, Rauch and Tocoian 2012). Muendler, Rauch and Tocoian (hereafter MRT) were the first to tabulate employee spinoffs for an entire economy: depending on definition, employee spinoffs account for between one-sixth and onethird of all new formal private sector firms in Brazil during the period 1995-2001. They found that, regardless of definition, employee spinoffs perform better on average than new firms without (identifiable) parents: their sizes at entry are larger and their survival rates are higher.

The industry studies by Klepper and Sleeper (2005) and Franco and Filson (2006) convincingly established that employee spinoffs learn their parents' technologies. In this paper, we investigate whether they also learn information about their parents' markets, by which we mean knowledge pertaining to demand rather than supply. The importance of the demand side for firm performance is increasingly recognized (Foster, Haltiwanger and Syverson 2008, 2016, Kee and Krishna 2008, Gourio and Rudanko 2014, Bernard et al. 2017). Does an employee spinoff in effect free-ride on its parent's "accumulation" of a "customer base" (Foster, Haltiwanger and Syverson 2016, p. 91)? This could be an additional explanation for the superior spinoff performance relative to new firms without parents found in the literature (Phillips 2002, Eriksson and Kuhn 2006, Muendler, Rauch and Tocoian 2012).

In the data sets in the literature that permit identification of employee spinoff firms and their parents, firm customers are not also identified. Here we take advantage of the "unique laboratory" that exporting firms provide "because we have good data on sales broken down by market" (Fitzgerald, Haller and YedidLevi 2016, p. 1). We have been able to link the data used in MRT to Brazilian firm level export data, and thereby observe the extent to which employee spinoffs export to the same markets (destination countries) as their parents. In this regard our study resembles the export spillover literature (Aitken, Hanson and Harrison 1997, Greenaway, Sousa and Wakelin 2004, Koenig, Mayneris and Poncet 2010, Fernandes and Tang 2014), which finds evidence that firms are more likely to export when other firms in the same industry and locality export.

The earlier papers in this literature (Aitken, Hanson and Harrison 1997, Greenaway, Sousa and Wakelin 2004) focused on spillovers from multinational enterprises (MNEs) in the same industry and locality, whereas the more recent papers (Koenig, Mayneris and Poncet 2010, Fernandes and Tang 2014) consider other domestic firms and look for spillovers to specific export destinations, i.e., evidence that firm exports to specific countries are more likely when neighboring domestic firms export to those countries. Our study 
more closely resembles the more recent papers but, as we will show, exporting parents in Brazil are, like MNEs, typically prominent (large) firms. We can expect other firms in the same industry and locality as them to export to the same countries, not only because of similar comparative advantage, but also because the parent firms are natural targets for imitation. We therefore want to investigate whether employee spinoffs export to their parents' markets to a greater extent than other firms in the same industries and localities as the parents, with the intention to provide evidence as to whether intrafirm learning gives them an extra advantage beyond what could be expected from the export spillover literature.

We find that the countries to which employee spinoffs export overlap with the countries to which their parents export to a much greater extent than comparison firms in the same industries and municipalities as the parents. This is true even if we control for the much greater overlap of spinoff exports with the products exported by their parents, which reflects the technologies they learned from their parents. However, greater export product overlap may not capture completely the extent to which employee spinoffs are more technologically similar to their parents than the comparison firms, and hence more likely to export to the same countries. For this reason we conduct a falsification test. If greater spinoff overlap with parent export markets is the result of intrafirm learning, spinoffs should not have greater overlap with new parent export markets, i.e, countries to which the parent was not exporting when the spinoff firm entered. This is indeed what we find.

We also find that the comparison firms that are most closely matched to parent firm industries and municipalities tend over time to catch up to the spinoffs from those parents in terms of export market overlap. A conservative interpretation of our results, then, is that intrafirm learning does not give spinoffs a permanent advantage in accessing their parents' markets, but rather a head start over the comparison firms that are best positioned to benefit from traditional export spillovers.

The work of Mion and Opromolla (2014) is closely related to ours. They also link matched firmworker data to export data (for Portugal), but are not concerned with employee spinoff firms. Instead they examine mobility of managers from firms that export to specific markets to other firms that export to the same markets. ${ }^{1}$ They find that these managers earn wage premia in their new firms, controlling for firm and worker fixed effects, a host of time-varying worker, past employer, and current employer characteristics, and mobility itself. Our results support their interpretation that these wage premia can be attributed to the managers' previous experience with the specific export markets. ${ }^{2}$ Mion and Opromolla also find that firms

\footnotetext{
${ }^{1}$ They group countries into seven markets: Spain; Italy, UK, France, and Germany; other EU countries; OECD countries not belonging to the EU; countries belonging to the Community of Portuguese Language Countries; China; and the rest of the world.

${ }^{2}$ An alternative interpretation is that firms that export to the same markets are alike in ways not captured by the included firmlevel characteristics, and the wage premia reflect better match quality between the managers and the firms to which they have moved, as in Jovanovic (1979). Mion and Opromolla do not offer a falsification test for their wage premia result.
} 
to which managers moved are more likely to begin exports to the markets served by their former employers or continue exports to these markets, though not export more in value. They support a causal interpretation of these findings by instrumenting for managers' export experience with their export experience three years prior to the year in which they measure trade performance. They do not compare export behavior of firms that are well positioned to learn at arm's length from the managers' former employers with that of the firms that hire the managers. Labanca, Molina and Muendler (2014) turn to the labor-demand side and show for the Brazilian matched firm-worker data that portable knowledge can be the cause of targeted hiring: firms that anticipate favorable export-market conditions, predicted by foreign product-demand shocks as instrumental variables, prepare themselves by poaching workers with prior export-market experience away from their employers, especially managers in marketing-related positions and blue-collar production workers.

More generally, our paper is related to the growing international trade literature on firm-level learning about export demand. Albornoz et al. (2012) find that, once firms learn they are profitable in their first export market, they enter additional markets in a process of "sequential exporting," because some elements of cost and demand that determine profitability are common across markets. Bastos and Silva (2012) find that firm entry into foreign markets increases with the presence of emigrants from the firm's country, indicating that the emigrants help the firm learn about demand in the target market. Eaton et al. (2014) estimate a structural model in which firm success with a buyer in a foreign market reveals information about the appeal of its product, encouraging the firm to pursue other buyers in that market. Timoshenko (2015b) finds that the tendency for exporting firms to add or drop products decreases with consecutive previous years of exporting, indicating that they are learning which of their products appeal to foreign consumers. Timoshenko (2015a) finds that both current probability of exporting and export sales increase with number of consecutive previous years of exporting, a proxy for learning.

The next section of our paper describes our data and our identification of employee spinoffs, their parents, and comparison firms. Section 3 examines the extent to which spinoffs share their parents' export destinations in their entry years relative to comparison firms that also export in the spinoffs' entry years. Section 4 does the same for the years following spinoff entries. In section 5 we investigate whether firm entry into parent markets predicted by spinoff status leads to entry into "adjacent" markets the following year. Section 6 concludes. An appendix offers complementary evidence from propensity matching of control firms to spinoffs rather than parents. 


\section{Employee Spinoffs, Parents, and Comparison Firms}

The data used by MRT derive from the linked employer-employee records RAIS (Relação Anual de Informações Sociais of the Brazilian labor ministry MTE), which record comprehensive individual employee information along with employer identifiers. By Brazilian law, every private or public-sector employer must report this information every year. ${ }^{3}$

The rules on tax ID assignments make it possible to identify new firms (the first eight digits of the tax ID) and new plants within firms (the last six digits of the tax ID). Our raw RAIS records include 71.1 million employees (with 556.3 million job spells) at 5.52 million plants in 3.75 million firms over the sixteen-year period 1986-2001 in any sector of the economy. We limit our attention to the years 1995-2001 and use the period 1986-1994 in RAIS to ensure that firms we label as new in 1995-2001 have not operated before. ${ }^{4}$ Moreover, RAIS does not specify the legal form of firms until 1995, information that is needed to carefully identify employee spinoffs as described below. During this 7-year period 1.54 million new firms entered.

MRT use two alternative criteria to identify employee spinoff firms and their parents and show the robustness of results under either criterion. For their preferred employee spinoff definition, they restrict their attention to new firms with at least five employees and use the criterion that if at least one quarter of the workers at a new firm previously worked for the same existing firm, the new firm is an employee spinoff and the existing firm is its parent. ${ }^{5}$ However, if this new firm absorbed at least seventy percent of the workers in one of the parent's plants and has a legal form such that it could be owned by the parent, MRT classify it as a divestiture (an employer-initiated spinoff) rather than an employee spinoff. ${ }^{6}$ MRT find that the performance of spinoffs is superior to new firms without parents but inferior to divestitures. In particular, size at entry is larger among employee spinoffs than among new firms without parents but smaller than among divestitures, and subsequent exit rates (controlling for size at entry) for employee spinoffs are smaller than for new firms without parents but larger than for divestitures. We use MRT's criteria to distinguish employee spinoffs from

\footnotetext{
${ }^{3}$ RAIS primarily provides information to a federal wage supplement program (Abono Salarial), by which every employee with formal employment during the calendar year receives the equivalent of a monthly minimum wage. RAIS records are then shared across government agencies. An employer's failure to report complete workforce information can, in principle, result in fines proportional to the workforce size, but fines are rarely issued. In practice, employees and employers have strong incentives to ascertain complete RAIS records because payment of the annual public wage supplement is exclusively based on RAIS. The ministry of labor estimates that well above 90 percent of all formally employed individuals in Brazil are covered in RAIS throughout the 1990 s.

${ }^{4}$ By 1995 macroeconomic stabilization had succeeded in Brazil. The Plano Real from August 1994 had brought inflation down to single-digit rates. Fernando Henrique Cardoso, who had enacted the Plano Real as Minister of Finance, became president, signalling a period of financial calm and fiscal austerity. Apart from a large exchange-rate devaluation in early 1999 and a subsequent switch from exchange-rate to inflation-targeting at the central bank, macroeconomic conditions remained relatively stable throughout the period.

${ }^{5}$ Previous work for the parent is defined as a job spell of at least three months.

${ }^{6} \mathrm{~A}$ new firm that has a legal form such that it could be owned by the parent but that absorbed less than 70 percent of workers from a parent plant are classified as spinoffs. Empirical results in MRT are robust to dropping these firms.
} 
new firms without parents and from divestitures. By these criteria, 29.0 percent of new firms in Brazil's domestically-owned private sector (that is, excluding firms with state or foreign ownership) in the period 1995-2001 with at least five employees are employee spinoffs.

Using firm IDs, we merge our data from RAIS with the universe of Brazilian customs declarations for merchandise exports collected at SECEX (Secretaria de Comércio Exterior), which reports exports by firm, destination market and product category over the period 1990-2001. The SECEX data record 234 destinations and 8,575 products at the eight-digit Harmonized Tariff System (HS) level. ${ }^{7}$

We examine the extent to which the export destinations of employee spinoffs overlap with those of their parents, compared to firms the literature has shown to be well positioned to learn the parents' markets at arm's length. We focus our analysis on the entry years of the spinoffs. In subsequent years, spinoffs may learn about parent markets at a distance, like the firms to which we compare them. Information from prior years could be useful if we knew when the spinoff owners were employed at the parent, but unfortunately we do not observe owners in RAIS.

Table 1 documents our sample construction from the combined raw data and shows why a large data set is helpful to conduct this study. Beginning with a set of over 96,000 employee spinoff firms and nearly 74,000 parent firms, we are reduced to a sample of only 446 spinoffs and 417 parents that both export in the entry year of the spinoff. Most of the sample reduction is a consequence of the requirement that firms have to export in order for us to observe their markets: only two percent of our spinoffs ever export during the sample period. This lack of exports is partly explained by the fact that most spinoffs are in nontraded goods industries (78 percent in Commerce or Service) and partly explained by the fact that they are small (the median and mean number of employees are 6 and 13, respectively). Spinoffs that export are, of course, mostly in traded goods industries (69 percent in Manufacturing or Agriculture and Mining), and are larger (the median and mean number of employees are 10 and 48, respectively). ${ }^{8}$ Spinoffs that export in their entry years are even more concentrated in traded goods industries and still larger, and these features are yet more prominent in spinoffs that export in their entry years from parents that export in those years.

To gauge the importance of employee spinoffs for the extensive margin of new exports in Brazil, we can compute their share of all new firms with at least five employees that export in their entry years, and their share of all new exporters including existing firms with at least five employees. We count an existing firm as a new exporter if it did not export in the previous year. Using these definitions, new firms accounted for 7.9 percent of new Brazilian exporters during our sample period 1995-2001, and employee spinoffs accounted

\footnotetext{
${ }^{7}$ Because of confidentiality concerns, SECEX reduced the level of firm-level detail after 2001. In an earlier version of this paper we conducted the analysis at the six-digit HS level and found nearly identical results.

${ }^{8}$ Most exporting spinoffs in "nontraded" goods industries are in Commerce and are presumably wholesalers.
} 


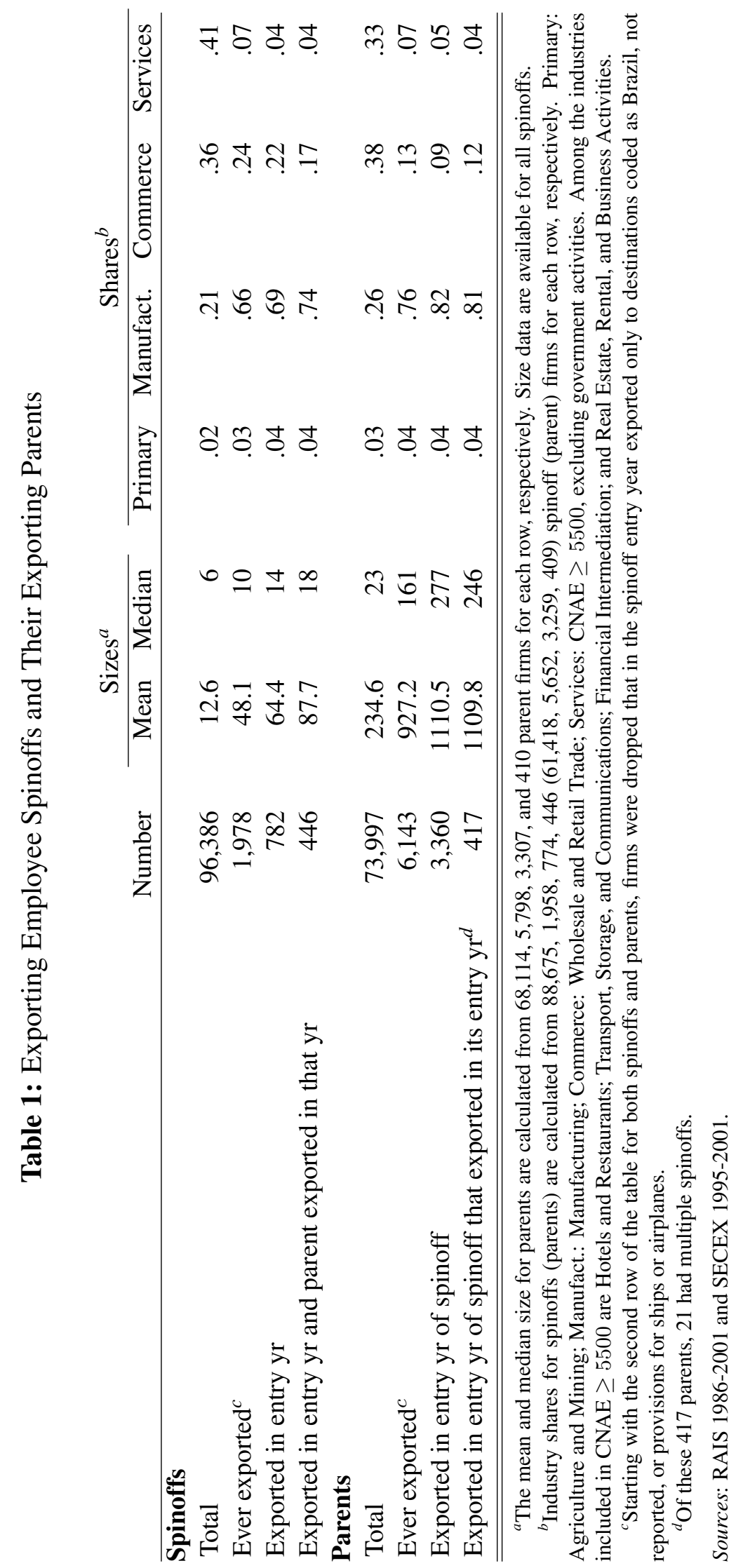


for 35.6 percent of new firm exporters or 2.8 percent of all new exporters.

More than four-fifths of our final sample of parent firms are in manufacturing, and the median and mean numbers of employees are both more than an order of magnitude larger than the corresponding figures for our final spinoff sample. ${ }^{9}$ The same is nearly true of the median and mean sizes of parent firms relative to our comparison firm samples (see Table 2). Thus parents are typically among the most prominent firms in their industries and localities and hence likely targets for imitation and learning.

Following the export spillover literature, we next seek firms that also exported in the spinoff entry years and that are well positioned to learn from the parents by virtue of being in the same industries and localities. We identify firm industry and locality by the mode industry and locality assigned to its employees in the entry year of the relevant spinoff. The most disaggregated industries and localities we have are 4digit CNAE (Classificação Nacional de Atividades Econômicas) and municipalities, respectively. In 2002 there were 564 4-digit CNAE industries, and in 2000 there were Brazilian 5,507 municipalities, with a mean population of 30,795 (Instituto Brasileiro de Geografia e Estatística). This compares to 1294-digit MEXSIC industries and 32 Mexican states in Aitken, Hanson and Harrison (1997); 645 5-digit SIC (1992) industries without controlling for UK locality in Greenaway, Sousa and Wakelin (2004); 1,236 4-digit products and 341 "employment areas" for France in Koenig, Mayneris and Poncet (2010); and 425 Chinese cities without controlling for industry in Fernandes and Tang (2014), though they find their results are robust to the use of textile firms only.

Unfortunately, only 239 out of the 446 spinoffs in our sample have comparison firms that exported in their entry years and are in the same 4-digit industries and municipalities as their parents. We considered two ways to expand coverage of spinoffs. One way is to use more aggregated industries and localities, specifically 3-digit CNAE and states. In 2002 there were 218 3-digit CNAE industries, and there are 26 Brazilian states. Of the 446 spinoffs in our sample, 416 or 93 percent have comparison firms in the same 3-digit industries and states as their parents. A second way to expand spinoff coverage is to continue to insist that comparison firms be in the same 4-digit industries as the spinoffs' parents, but replace the locality restriction with a control for distance from the relevant parent in our regressions below. Of the 446 spinoffs, 437 have comparison firms in the same 4-digit industries as their parents. Not surprisingly, the main effect of including comparison firms that are less well positioned to learn from the parent firms is to increase the difference between spinoff and comparison firms in overlap with parent export destinations. Our results do not change qualitatively, except that even after six years comparison firms do not catch up

\footnotetext{
${ }^{9}$ For a parent firm we record number of employees for the year before the spinoff entry year, since in the spinoff entry year the parent may not yet have been able to replace the employees lost to its spinoff. For seven of the 417 parents in our final sample we were not able to obtain the previous year's number of employees from RAIS.
} 
to spinoff firms in terms of export market overlap. We report all of these findings in an Online Supplement (http://econweb.ucsd.edu/ jrauch/pdfs/spinlearn-suppl.pdf).

Table 2 shows the same descriptive information for the comparison firms that Table 1 showed for spinoffs and parents. ${ }^{10}$ We see that the comparison firms are much larger than the spinoffs, though nearly an order of magnitude smaller than the parents, probably because they are not (necessarily) new firms. We also note that many comparison firms are duplicated because they fit the selection criteria for more than one parent-spinoff pair. $^{11}$

\section{Exports of Spinoff Versus Comparison Firms in Spinoff Entry Years}

We first confirm that spinoffs tend to make the same products as their parents, as has been found in the industry studies cited in our introduction. Were this not true, it would raise suspicions regarding the quality of our data. We examine the share of parent export products that are also spinoff export products versus also comparison firm export products. Specifically, we compute export product overlap as (number of export products same as parent export products)/(number of parent export products).

Table 3 shows that parents export a median of 5 and a mean of 16.2 HS8 products in the entry years of their spinoffs. Their spinoffs export a median of 2 and a mean of 5.0 HS8 products in their entry years, and their comparison firms export a median of 2 and a mean of 5.7 HS8 products in the spinoffs' entry years. Despite the slightly larger number of products exported by the comparison firms, the share of parent products also exported by spinoffs is 21 percentage points higher on average. We can also consider the cases where both parent and spinoff or parent and comparison firm each exports only one product. The spinoff exports the same product as the parent in 74 percent of these cases, versus only 28 percent for the comparison firms.

Table 3 documents that the exporting employee spinoffs we have identified in Brazil display high capability to produce and export the same products as their parents, both absolutely and relative to other exporting firms in the parents' industries and municipalities. This is what we would expect based on the capabilities displayed by the spinoffs in U.S. industry studies. ${ }^{12}$ Now we would like to go beyond the existing literature

\footnotetext{
${ }^{10}$ Industry or municipality data were missing in the spinoff entry years for seven of the 417 parent firms in our final sample in Table 1. Using data from up to two years earlier, we were able to fill in the missing information for six of these seven parents. We then used the same procedure to fill in missing industry or municipality information for two of the comparison firms. We repeated all tables in the remainder of this paper dropping these comparison firms, and found that all results were qualitatively unchanged (and very little changed quantitatively). We then dropped the six filled-in parent firms as well, along with their associated spinoff and comparison firms, repeated all tables again, and found the same thing.

${ }^{11}$ Table 2 shows that the mean sizes for all comparison firms are always slightly higher than for unique comparison firms. Note that comparison firms can repeat when i) they are cited by more than one parent, or ii) a parent has multiple spinoffs. In either case, we have a reason to believe that the market that supports the particular industry-municipality combination is especially robust because it supports more firms. Comparison firms operating in these markets are therefore likely to be larger, all else equal.

${ }^{12}$ It is presumed in these studies that spinoffs learned these abilities from their parents. We also believe this, but we do not claim
} 


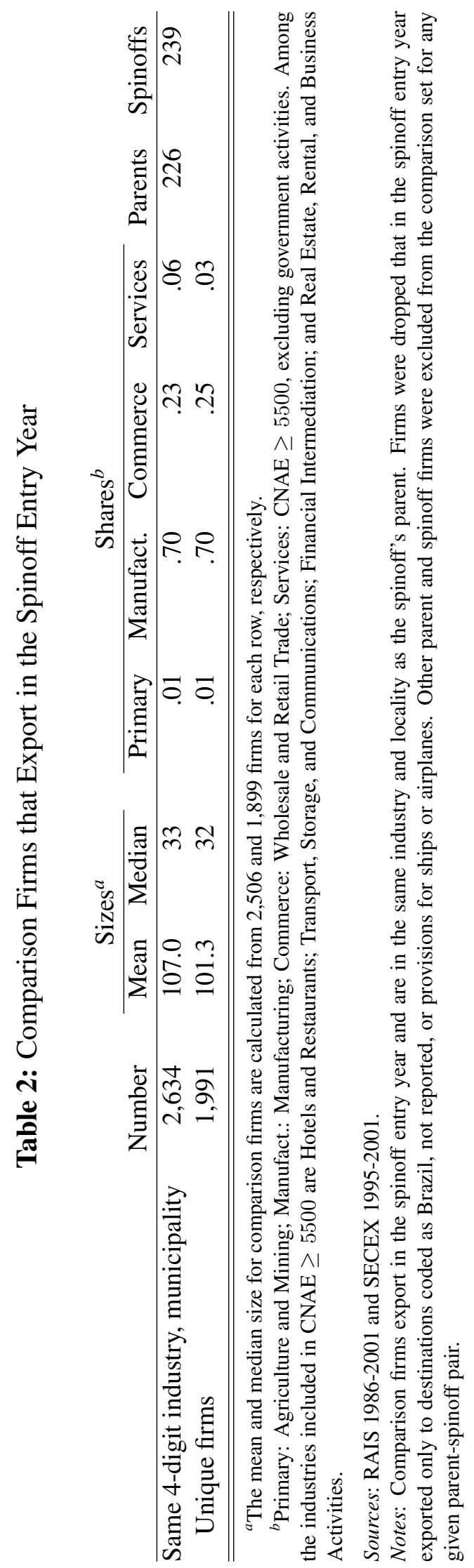


Table 3: Descriptive Statistics for Export Products in Spinoff Entry Years

\begin{tabular}{lrrrrrr} 
& Mean & Std. Dev. & Median & Maximum $^{a}$ & Unique $^{b}$ & Number $^{c}$ \\
\cline { 2 - 7 } & \multicolumn{1}{c}{$(1)$} & $(2)$ & $(3)$ & $(4)$ & $(5)$ & $(6)$ \\
\hline Parent no. & 16.18 & 29.71 & 5 & 173 & .21 & $239^{c}$ \\
Spinoff no. & 4.97 & 12.56 & 2 & 150 & .48 & 239 \\
Comparison no. & 5.73 & 14.35 & 2 & 241 & .41 & 2,634 \\
Spin. overlap & .39 & .37 & .26 & 1 & .74 & 239 \\
Comp. overlap & .18 & .31 & .00 & 1 & .28 & 2,634 \\
\hline \hline
\end{tabular}

\footnotetext{
${ }^{a}$ The minimum number of products is always one and the minimum overlap is always zero.

${ }^{b}$ For the first three rows, this column gives the fraction of firms that exported only one product. For the last two rows, this column gives the fraction of spinoff or comparison firms that shared the unique product with the corresponding parent firms.

${ }^{c}$ Parents with multiple spinoffs are counted multiple times.

Sources: RAIS 1986-2001 and SECEX 1995-2001.

Notes: The total number of HS8 products recorded for this sample is 3,760, out of a possible 8,575 from the SECEX data.
}

to ask whether exporting employee spinoffs learn about their parents' markets more than other exporting firms in the parents' industries and municipalities. We address this in Table 4, parallel to Table 3, and examine the share of parent export destinations to which their spinoffs and the comparison firms also export. Since any Brazilian product may be better suited for some destinations than others (comparative advantage), ultimately we go beyond descriptive statistics to a conditional analysis in Table 5, where we control for the greater extent to which spinoff export products overlap with those of their parents.

Table 4 shows that parents export to a median of 5 and a mean of 9.3 destinations in the entry years of their spinoffs. Their spinoffs export to a median of 1 and a mean of 3.2 destinations in their entry years, and their comparison firms export to a median of 2 and a mean of 3.3 destinations in the spinoffs' entry years. The share of parent destinations to which spinoffs also export is 18 percentage points higher on average than the share of parent destinations to which comparison firms also export. Considering the cases where both parent and spinoff or parent and comparison firm each exports to only one destination, the spinoff exports to the same destination as the parent in 81 percent of these cases, versus only 32 percent for the comparison firms.

In Table 5 we regress the share of parent firm destinations to which spinoffs and comparison firms also export on an indicator for whether a firm is the parent's spinoff and various controls. Because there are typically multiple comparison firm observations for each spinoff observation, we cluster standard errors at the spinoff-year level. The coefficient on the spinoff indicator in the first column of Table 5 reproduces the

this is proved by Table 3. It could be that the greater overlap of spinoff products with parent products is driven by unobserved greater similarities to the parents relative to the comparison firms that are somehow unconnected to spinoff learning from parents. We will be more concerned with supporting a learning interpretation when we discuss spinoff overlap with parent markets. 
Table 4: Descriptive Statistics for Export Destinations in Spinoff Entry Years

\begin{tabular}{lrrrrrr} 
& Mean & Std. Dev. & Median & Maximum $^{a}$ & Unique $^{b}$ & Number $^{c}$ \\
\cline { 2 - 7 } & \multicolumn{1}{c}{$(1)$} & $(2)$ & $(3)$ & $(4)$ & $(5)$ & $(6)$ \\
\hline Parent no. & 9.28 & 10.88 & 5 & 61 & .22 & $239^{c}$ \\
Spinoff no. & 3.22 & 4.65 & 1 & 43 & .51 & 239 \\
Comparison no. & 3.30 & 4.32 & 2 & 45 & .46 & 2,634 \\
Spin. overlap & .43 & .36 & .33 & 1 & .81 & 239 \\
Comp. overlap & .25 & .32 & .09 & 1 & .32 & 2,634 \\
\hline \hline
\end{tabular}

\footnotetext{
${ }^{a}$ The minimum number of destinations is always one and the minimum overlap is always zero.

${ }^{b}$ For the first three rows, this column gives the fraction of firms that exported to only one destination. For the last two rows, this column gives the fraction of spinoff or comparison firms that shared the unique destination with the corresponding parent firms.

${ }^{c}$ Parents with multiple spinoffs are counted multiple times.

Sources: RAIS 1986-2001 and SECEX 1995-2001.

Notes: The total number of destinations recorded for this sample is 167, out of a possible 234 from the SECEX data.
}

difference between spinoff overlap and comparison firm overlap shown in Table 4. The second column adds industry, locality, and year fixed effects. The third column controls for the number of spinoff or comparison firm export destinations and the number of parent export destinations, since all else equal the former will tend to increase the dependent variable and the latter will tend to decrease it. Looking across these three columns we see that the addition of the controls hardly changes the extent to which the spinoff share of parent export destinations exceeds the comparison firm share. In sharp contrast, the addition of the share of parent export products as a control in the fourth column reduces the coefficient on the spinoff indicator by roughly six percentage points. Nevertheless, this coefficient remains high at 12.6 percentage points (more than 50 percent higher than the comparison mean of 24.9 percentage points) and continues to be precisely estimated at conventional levels of significance. The strong effect of comparative advantage is indicated by the fact that increasing the share of parent export products also exported by spinoff or comparison firms from zero to one hundred percent increases their share of parent destinations by 25 percentage points.

\section{Post-Entry Year Destination Overlaps Between Spinoffs and Parents}

Our hypothesis is that employees who found spinoff firms learn the identities, preferences, and idiosyncrasies of the parent firms' customers and the regulatory environments of the destinations in which those customers operate, giving them an advantage in serving those customers and destinations over otherwise similarly situated domestic competitors. An alternative hypothesis is that employee spinoffs resemble their parents more than other firms in the same industry and municipality in ways not captured by product overlap, causing their output to sell well in the same markets as their parents' output. In other words, employee 
Table 5: Regressions for Parent Export Destinations in Spinoff Entry Years

\begin{tabular}{lcccc} 
& base & controls & count & wProd \\
\cline { 2 - 5 } & $(1)$ & $(2)$ & $(3)$ & $(4)$ \\
\hline Spinoff & $.182^{* * *}$ & $.178^{* * *}$ & $.189^{* * *}$ & $.126^{* * *}$ \\
& $(.026)$ & $(.023)$ & $(.022)$ & $(.020)$ \\
Spinoff/Comp Destinations & & & $.030^{* * *}$ & $.028^{* * *}$ \\
& & & $(.002)$ \\
Parent Destinations & & & $-.009^{* * *}$ & $-.008^{* * *}$ \\
& & & $(.002)$ & $(.002)$ \\
Product overlap & & & & $.254^{* * *}$ \\
& & & & $(.028)$ \\
Const. & $.249^{* * *}$ & -.052 & .024 & -.049 \\
& $(.018)$ & $(.065)$ & $(.067)$ & $(.056)$ \\
Observations & 2,873 & 2,873 & 2,873 & 2,873 \\
$R^{2}$ & .023 & .262 & .415 & .441 \\
Spinoffs & 239 & 239 & 239 & 239 \\
Comparisons & 2,634 & 2,634 & 2,634 & 2,634 \\
\hline \hline
\end{tabular}

Sources: RAIS 1986-2001 and SECEX 1995-2001.

Notes: Dependent variable is spinoff/comparison overlap with parent export destinations in spinoff entry years. Starting with the "controls" column, all columns have 4-digit industry, municipality, and year controls. Standard errors are clustered by spinoff-year.

${ }^{* * *}$ significance at one, ${ }^{* *}$ five, ${ }^{*}$ ten percent levels.

spinoffs do not have an informational advantage in reaching their parents' markets but rather what might be called a genetic advantage.

The genetic advantage hypothesis is a typical case of correlated unobservables. A natural response is to seek an instrument for spinoff status. However, it is impossible to conceive of an instrument that would cause the employees who establish a spinoff to transfer tacit demand-side but not supply-side knowledge acquired from the parent firm. In the absence of a conceptually valid instrument, we conduct a placebo or falsification test to distinguish the informational demand-side from the genetic supply-side advantage hypothesis. We investigate whether spinoffs overlap more than comparison firms with parent export destinations to which the parents did not export in the spinoff entry years. If the parent did not export to these destinations when the employees who founded the spinoff worked there, they could not have learned about the customers and destination regulatory environments from working at the parent. Under the informational advantage hypothesis, then, spinoff firms will not have a greater overlap with parents' "new" export destinations than will their competitors, the comparison firms. ${ }^{13}$ On the other hand, if spinoffs overlap more with parents'

\footnotetext{
${ }^{13}$ We treat any destinations to which the parents export in years subsequent to the entries of their spinoffs but to which they did not export in the spinoff entry years as "new." In fact, the parents may have exported to these destinations before the spinoffs entered. It is therefore possible that the spinoff entrepreneurs were positioned to learn these markets. We do not know, because we cannot observe them. Excluding these destinations would work against finding greater overlap of spinoffs with "new" parent export
} 
entry-year export destinations because they are more like the parents than their competitors, they should be better positioned to take advantage of the same opportunities as their parents in new export markets as well (or, equivalently, buyers in new export markets who find their parents' products attractive should also find the spinoffs' products attractive, relative to their competitors).

We want the placebo regressions to imitate the regressions in Table 5 as closely as possible. Recall that parents are included in the Table 5 sample only if they export in the spinoff entry years, have spinoffs that export in those years, and have comparison firms that export in those years. Thus, for each year following the spinoff entry, we retain from the Table 5 sample only those parents that export to at least one new destination in that year, have spinoffs that export (to any destination) in that year, and have comparison firms that export (to any destination) in that year.

Our data cover the period 1995-2001, so there can be at most six years (1996-2001) following spinoff entry. We label the years following spinoff entry $t+1$ through $t+6$, where $t+6$ is necessarily calendar year 2001, $t+5$ could be calendar year 2000 or 2001, etc. Any spinoff or comparison firms associated with parents that are retained in the regressions but do not themselves export in a given year $t+1$ through $t+6$ are dropped for that year.

In Table 6, the dependent variable is spinoff and comparison firm overlap with new parent firm destinations. We follow the parent, spinoff, and comparison firms from Table 5 through time, starting from one year after spinoff entry through six years after spinoff entry. For each year we lose one cohort of spinoffs and associated parent and comparison firms, so that by $t+6$ only the 1995 cohort remains. We also lose the observations for which the parent firm did not export to any new destination, or for which the parent's spinoff did not export at all, or for which there was no exporting comparison firm. Thus in $t+1$ the number of spinoff observations drops to about one-third of its level in Table 5, and continues to decline as we move toward $t+6$.

For $t+1$ in Table 6 we see that the point estimates on the spinoff indicator are close to zero and not statistically significant at conventional levels, regardless of which controls are included. This lack of statistical significance continues to hold for $t+2$ through $t+4$, though the point estimates are more consistently positive. For $t+5$ the point estimates are substantial without controls though still not statistically significant, and become close to zero when controls are added. For $t+6$ the point estimates on the spinoff indicator are comparable to those in Table 5, though still not statistically significant. At this point there are only four spinoffs left.

The constant terms in the regressions without any controls in Table 6 equal the mean overlaps of com-

destinations and reduce the number of observations, both of which would make it less likely to find statistically significant positive coefficients on the spinoff indicator in the placebo regressions. 
Table 6: Regressions for New Parent Export Destinations, years $t+1$ through $t+6$

\begin{tabular}{|c|c|c|c|c|c|c|c|c|c|}
\hline \multicolumn{5}{|c|}{$t+1$} & \multicolumn{5}{|c|}{$t+2$} \\
\hline & base & controls & count & wProd & & base & controls & count & wProd \\
\hline Spinoff & $\begin{array}{l}-.003 \\
(.035)\end{array}$ & $\begin{array}{l}.005 \\
(.033)\end{array}$ & $\begin{array}{c}-.004 \\
(.030)\end{array}$ & $\begin{array}{c}-.008 \\
(.029)\end{array}$ & Spinoff & $\begin{array}{l}.045 \\
(.046)\end{array}$ & $\begin{array}{l}.020 \\
(.051)\end{array}$ & $\begin{array}{l}.017 \\
(.051)\end{array}$ & $\begin{array}{l}.014 \\
(.048)\end{array}$ \\
\hline Spin/Comp Dest. & & & $\begin{array}{c}.024^{* * *} \\
(.002)\end{array}$ & $\begin{array}{c}.024^{* * *} \\
(.003)\end{array}$ & Spin/Comp Dest. & & & $\begin{array}{c}.019^{* * *} \\
(.003)\end{array}$ & $\begin{array}{c}.019^{* * *} \\
(.003)\end{array}$ \\
\hline Parent New Dest. ${ }^{a}$ & & & $\begin{array}{c}-.029^{* * *} \\
(.007)\end{array}$ & $\begin{array}{c}-.029^{* * *} \\
(.007)\end{array}$ & Parent New Dest. ${ }^{a}$ & & & $\begin{array}{c}.001^{* * *} \\
(.0003)\end{array}$ & $\begin{array}{l}.001^{*} \\
(.0008)\end{array}$ \\
\hline Product overlap ${ }^{b}$ & & & & $\begin{array}{l}.072 \\
(.112)\end{array}$ & Product overlap ${ }^{b}$ & & & & $\begin{array}{l}.023 \\
(.170)\end{array}$ \\
\hline Const. & $\begin{array}{c}.138^{* * *} \\
(.021)\end{array}$ & $\begin{array}{l}.179 \\
(.201)\end{array}$ & $\begin{array}{l}.210 \\
(.177)\end{array}$ & $\begin{array}{l}.209 \\
(.176)\end{array}$ & Const. & $\begin{array}{c}.108^{* * *} \\
(.024)\end{array}$ & $\begin{array}{c}.661^{* * *} \\
(.009)\end{array}$ & $\begin{array}{c}.569^{* * *} \\
(.021)\end{array}$ & $\begin{array}{c}.566^{* * *} \\
(.029)\end{array}$ \\
\hline Obs & 788 & 788 & 788 & 788 & Obs & 552 & 552 & 552 & 552 \\
\hline $\mathrm{R}^{2}$ & $7.18 \mathrm{e}-06$ & .238 & .406 & .407 & $\mathrm{R}^{2}$ & .002 & .328 & .448 & .448 \\
\hline Spinoffs & 76 & 76 & 76 & 76 & Spinoffs & 48 & 48 & 48 & 48 \\
\hline Comparisons & 712 & 712 & 712 & 712 & Comparisons & 504 & 504 & 504 & 504 \\
\hline \multicolumn{5}{|c|}{$t+3$} & \multicolumn{5}{|c|}{$t+4$} \\
\hline & base & $\overline{\text { controls }}$ & count & wProd & & base & $\overline{\text { controls }}$ & count & wProd \\
\hline Spinoff & $\begin{array}{l}.035 \\
(.068)\end{array}$ & $\begin{array}{l}.041 \\
(.080)\end{array}$ & $\begin{array}{l}.059 \\
(.070)\end{array}$ & $\begin{array}{l}.055 \\
(.071)\end{array}$ & Spinoff & $\begin{array}{l}.046 \\
(.084)\end{array}$ & $\begin{array}{l}.041 \\
(.091)\end{array}$ & $\begin{array}{l}.054 \\
(.081)\end{array}$ & $\begin{array}{l}.042 \\
(.076)\end{array}$ \\
\hline Spin/Comp Dest. & & & $\begin{array}{c}.023^{* * *} \\
(.004)\end{array}$ & $\begin{array}{c}.022^{* * *} \\
(.004)\end{array}$ & Spin/Comp Dest. & & & $\begin{array}{c}.018^{* * *} \\
(.004)\end{array}$ & $\begin{array}{c}.017^{* * *} \\
(.003)\end{array}$ \\
\hline Parent New Dest. ${ }^{a}$ & & & $\begin{array}{c}.008^{* * *} \\
(.001)\end{array}$ & $\begin{array}{l}.006^{*} \\
(.003)\end{array}$ & Parent New Dest. ${ }^{a}$ & & & $\begin{array}{c}.029^{* * *} \\
(.002)\end{array}$ & $\begin{array}{c}.020^{* * *} \\
(.005)\end{array}$ \\
\hline Product overlap ${ }^{b}$ & & & & $\begin{array}{l}.106 \\
(.128)\end{array}$ & Product overlap ${ }^{b}$ & & & & $\begin{array}{c}.210^{* *} \\
(.092)\end{array}$ \\
\hline Const. & $\begin{array}{c}.160^{* * *} \\
(.033)\end{array}$ & $\begin{array}{c}-.099^{* *} \\
(.046)\end{array}$ & $\begin{array}{c}-.477^{* * *} \\
(.077)\end{array}$ & $\begin{array}{c}-.422^{* * *} \\
(.113)\end{array}$ & Const. & $\begin{array}{c}.177^{* * *} \\
(.043)\end{array}$ & $\begin{array}{c}-.077^{*} \\
(.041)\end{array}$ & $\begin{array}{c}-.193^{* * *} \\
(.052)\end{array}$ & $\begin{array}{c}-.268^{* * *} \\
(.059)\end{array}$ \\
\hline Obs & 247 & 247 & 247 & 247 & Obs & 163 & 163 & 163 & 163 \\
\hline $\mathrm{R}^{2}$ & .001 & .242 & .434 & .437 & $\mathrm{R}^{2}$ & .002 & .416 & .556 & .580 \\
\hline Spinoffs & 22 & 22 & 22 & 22 & Spinoffs & 16 & 16 & 16 & 16 \\
\hline Comparisons & 225 & 225 & 225 & 225 & Comparisons & 147 & 147 & 147 & 147 \\
\hline \multicolumn{5}{|c|}{$t+5$} & \multicolumn{5}{|c|}{$t+6$} \\
\hline & base & $\overline{\text { controls }}$ & count & wProd & & base & $\overline{\text { controls }}$ & count & wProd \\
\hline Spinoff & $\begin{array}{l}.077 \\
(.094)\end{array}$ & $\begin{array}{l}.044 \\
(.117)\end{array}$ & $\begin{array}{l}.048 \\
(.115)\end{array}$ & $\begin{array}{c}-.002 \\
(.105)\end{array}$ & Spinoff & $\begin{array}{l}.215 \\
(.235)\end{array}$ & $\begin{array}{l}.174 \\
(.264)\end{array}$ & $\begin{array}{l}.178 \\
(.254)\end{array}$ & $\begin{array}{l}.199 \\
(.274)\end{array}$ \\
\hline Spin/Comp Dest. & & & $\begin{array}{c}.017^{* * *} \\
(.003)\end{array}$ & $\begin{array}{c}.015^{* * *} \\
(.004)\end{array}$ & Spin/Comp Dest. & & & $\begin{array}{c}.013^{* * *} \\
(.005)\end{array}$ & $\begin{array}{c}.014^{* * *} \\
(.005)\end{array}$ \\
\hline Parent New Dest. ${ }^{a}$ & & & $\begin{array}{c}-.077^{* *} \\
(.033)\end{array}$ & $\begin{array}{l}-.125^{* * *} \\
(.037)\end{array}$ & Parent New Dest. ${ }^{a}$ & & & $\begin{array}{c}-.021^{* * *} \\
(.004)\end{array}$ & $\begin{array}{c}-.021^{* * *} \\
(.005)\end{array}$ \\
\hline Product overlap ${ }^{b}$ & & & & $\begin{array}{l}.317^{* *} \\
(.147)\end{array}$ & Product overlap $^{b}$ & & & & $\begin{array}{l}-.070 \\
(.351)\end{array}$ \\
\hline Const. & $\begin{array}{c}.196^{* * *} \\
(.056)\end{array}$ & $\begin{array}{c}.971^{* * *} \\
(.056)\end{array}$ & $\begin{array}{c}-1.121 \\
(.763)\end{array}$ & $\begin{array}{c}-2.544^{* * *} \\
(.938)\end{array}$ & Const. & $\begin{array}{c}.222^{* * *} \\
(.045)\end{array}$ & $\begin{array}{c}.413^{* * *} \\
(.132)\end{array}$ & $\begin{array}{c}.399^{* * *} \\
(.139)\end{array}$ & $\begin{array}{c}.414^{* *} \\
(.170)\end{array}$ \\
\hline Obs & 116 & 116 & 116 & 116 & Obs & 49 & 49 & 49 & 49 \\
\hline $\mathrm{R}^{2}$ & .005 & .453 & .570 & .606 & $\mathrm{R}^{2}$ & .043 & .224 & .287 & .289 \\
\hline Spinoffs & 13 & 13 & 13 & 13 & Spinoffs & 4 & 4 & 4 & 4 \\
\hline Comparisons & 103 & 103 & 103 & 103 & Comparisons & 45 & 45 & 45 & 45 \\
\hline
\end{tabular}

${ }^{a}$ Number of parent export destinations in year $t+k$ excluding those in spinoff entry years.

${ }^{b}$ Spinoff/comparison overlap in year $t+k$ with parent products exported to new destinations in year $t+k$.

Sources: RAIS 1986-2001 and SECEX 1995-2001.

Notes: Dependent variable is spinoff/comparison overlap with parent export destinations in year $t+k$ excluding those in spinoff entry years. Starting with the "controls" column, all columns have 4-digit industry, municipality, and year controls. Standard errors are clustered by spinoff-year. ${ }^{* * *}$ significance at one, ${ }^{* *}$ five, ${ }^{*}$ ten percent levels. 
parison firms with new parent destinations in $t+1$ through $t+6$. Note that these tend to rise over time, and by $t+6$ reach roughly their levels in Table 5 . This is consistent with the idea that comparison firms gradually learn about the parents' new markets at a distance, and with the idea that spinoffs also learn at a distance, given that their mean overlap with new parent destinations is not statistically significantly different from the comparison firms' mean overlap.

An alternative interpretation of the null results of these placebo tests is that something happens between the spinoff entry year and the following year $(t+1)$ to eliminate the spinoff advantage in accessing their parents' markets. It is conceivable that overseas markets change so rapidly, or that spinoffs so quickly become different from their parents, or that comparison firms catch up to spinoff learning so fast, that the spinoff advantage disappears within a year. The spinoff advantage is unlikely to last forever, but one might expect it to last for most or all of the six years our sample allows us to check.

Table 7 parallels Table 6, but the dependent variable is spinoff and comparison firm overlap with spinoff entry year ("initial") export destinations of the parent instead of parent non-entry year export destinations. For each year following the spinoff entry, we retain from the Table 5 sample only those parents that have both spinoff and comparison firms with exports in that year. In $t+1$ about three-quarters of spinoff observations from Table 5 are retained. The controls in Table 7 differ from those in Table 5 in two ways. First, the number of spinoff or comparison firm destinations takes its value in $t+1, \ldots, t+6$ instead of its value in the spinoff entry year. Second, the share of parent products exported by the spinoff or comparison firm is the share of spinoff entry year export products of the parent that the spinoff or comparison firm exported in $t+1, \ldots$, $t+6$ instead of in the spinoff entry year.

We see that in $t+1$ the coefficients on the spinoff indicator are slightly larger than the coefficients on the spinoff indicator in the entry year regressions (Table 5). The spinoff indicator coefficients shrink from $t+1$ to $t+2$ and again from $t+2$ to $t+3$, but remain statistically significant at conventional levels. From $t+4$ to $t+6$ the spinoff indicator coefficients remain roughly the same as in $t+3$, but the standard errors rise so that the coefficients are no longer statistically significant. Here is the one instance where use of the larger samples makes a qualitative difference to our results. For either the 3-digit industry, state sample or the 4-digit industry sample with a distance control, the spinoff indicator coefficients remain statistically significant from $t+4$ to $t+6$, both because the coefficients are larger and the standard errors are smaller (see Online Supplement). The larger samples include comparison firms less well positioned to learn the markets of the spinoffs' parents at arm's length. A reasonable interpretation of our results is therefore that, relative to these firms, intrafirm learning gives spinoffs a long-lasting advantage in accessing their parents' markets, but only a four-year head start (entry year through $t+3$ ) over the comparison firms in close geographical 
Table 7: Regressions for Initial Parent Export Destinations, years $t+1$ through $t+6$

\begin{tabular}{|c|c|c|c|c|c|c|c|c|c|}
\hline \multicolumn{5}{|c|}{$t+1$} & \multicolumn{5}{|c|}{$\underline{t+2}$} \\
\hline & base & controls & count & wProd & & base & controls & count & wProd \\
\hline Spinoff & $\begin{array}{c}.196^{* * *} \\
(.030)\end{array}$ & $\begin{array}{c}.198^{* * *} \\
(.029)\end{array}$ & $\begin{array}{c}.202^{* * *} \\
(.027)\end{array}$ & $\begin{array}{c}.136^{* * *} \\
(.028)\end{array}$ & Spinoff & $\begin{array}{c}.138^{* * *} \\
(.036)\end{array}$ & $\begin{array}{c}.161^{* * *} \\
(.035)\end{array}$ & $\begin{array}{c}.171^{* * *} \\
(.032)\end{array}$ & $\begin{array}{c}.110^{* * *} \\
(.030)\end{array}$ \\
\hline Spin/Comp Dest. & & & $\begin{array}{c}.031^{* * *} \\
(.002)\end{array}$ & $\begin{array}{c}.029^{* * *} \\
(.002)\end{array}$ & Spin/Comp Dest. & & & $\begin{array}{c}.031^{* * *} \\
(.003)\end{array}$ & $\begin{array}{c}.029^{* * *} \\
(.003)\end{array}$ \\
\hline Parent Initial Dest. ${ }^{a}$ & & & $\begin{array}{c}-.009^{* * *} \\
(.002)\end{array}$ & $\begin{array}{c}-.008^{* * *} \\
(.002)\end{array}$ & Parent Initial Dest. ${ }^{a}$ & & & $\begin{array}{c}-.013^{* * *} \\
(.003)\end{array}$ & $\begin{array}{c}-.012^{* * *} \\
(.003)\end{array}$ \\
\hline Product overlap ${ }^{b}$ & & & & $\begin{array}{c}.255^{* * *} \\
(.062)\end{array}$ & Product overlap ${ }^{b}$ & & & & $\begin{array}{c}.224^{* * *} \\
(.046)\end{array}$ \\
\hline Const. & $\begin{array}{c}.297^{* * *} \\
(.021)\end{array}$ & $\begin{array}{l}-.037 \\
(.073)\end{array}$ & $\begin{array}{c}-.034 \\
(.088)\end{array}$ & $\begin{array}{c}-.070 \\
(.071)\end{array}$ & Const. & $\begin{array}{c}.336^{* * *} \\
(.024)\end{array}$ & $\begin{array}{l}.088 \\
(.083)\end{array}$ & $\begin{array}{l}.195^{*} \\
(.106)\end{array}$ & $\begin{array}{c}.174^{* *} \\
(.086)\end{array}$ \\
\hline Obs & 1897 & 1897 & 1897 & 1897 & Obs & 1305 & 1305 & 1305 & 1305 \\
\hline $\mathrm{R}^{2}$ & .026 & .299 & .458 & .483 & $\mathrm{R}^{2}$ & .011 & .296 & .441 & .459 \\
\hline Spinoffs & 178 & 178 & 178 & 178 & Spinoffs & 113 & 113 & 113 & 113 \\
\hline Comparisons & 1719 & 1719 & 1719 & 1719 & Comparisons & 1192 & 1192 & 1192 & 1192 \\
\hline \multicolumn{5}{|c|}{$t+3$} & \multicolumn{5}{|c|}{$\underline{t+4}$} \\
\hline & base & controls & count & wProd & & base & controls & count & wProd \\
\hline Spinoff & $\begin{array}{l}.084^{*} \\
(.045)\end{array}$ & $\begin{array}{c}.103^{* *} \\
(.046)\end{array}$ & $\begin{array}{c}.125^{* * *} \\
(.040)\end{array}$ & $\begin{array}{c}.080^{* *} \\
(.036)\end{array}$ & Spinoff & $\begin{array}{l}.090 \\
(.057)\end{array}$ & $\begin{array}{l}.094 \\
(.060)\end{array}$ & $\begin{array}{c}.113^{* *} \\
(.056)\end{array}$ & $\begin{array}{l}.085 \\
(.054)\end{array}$ \\
\hline Spin/Comp Dest. & & & $\begin{array}{c}.028^{* * *} \\
(.003)\end{array}$ & $\begin{array}{c}.026^{* * *} \\
(.003)\end{array}$ & Spin/Comp Dest. & & & $\begin{array}{c}.025^{* * *} \\
(.003)\end{array}$ & $\begin{array}{c}.024^{* * *} \\
(.004)\end{array}$ \\
\hline Parent Initial Dest. ${ }^{a}$ & & & $\begin{array}{c}-.019^{* * *} \\
(.005)\end{array}$ & $\begin{array}{c}-.016^{* * *} \\
(.004)\end{array}$ & Parent Initial Dest. ${ }^{a}$ & & & $\begin{array}{l}-.005 \\
(.003)\end{array}$ & $\begin{array}{c}-.007^{*} \\
(.004)\end{array}$ \\
\hline Product overlap ${ }^{b}$ & & & & $\begin{array}{c}.193^{* * *} \\
(.050)\end{array}$ & Product overlap ${ }^{b}$ & & & & $\begin{array}{l}.123 \\
(.086)\end{array}$ \\
\hline Const. & $\begin{array}{c}.375^{* * *} \\
(.024)\end{array}$ & $\begin{array}{l}.092 \\
(.095)\end{array}$ & $\begin{array}{c}.330^{* * *} \\
(.119)\end{array}$ & $\begin{array}{c}.256^{* * *} \\
(.094)\end{array}$ & Const. & $\begin{array}{c}.348^{* * *} \\
(.029)\end{array}$ & $\begin{array}{l}-.096 \\
(.068)\end{array}$ & $\begin{array}{l}-.186 \\
(.135)\end{array}$ & $\begin{array}{l}-.114 \\
(.137)\end{array}$ \\
\hline Obs & 813 & 813 & 813 & 813 & Obs & 586 & 586 & 586 & 586 \\
\hline $\mathrm{R}^{2}$ & .004 & .314 & .461 & .477 & $\mathrm{R}^{2}$ & .005 & .342 & .462 & .468 \\
\hline Spinoffs & 72 & 72 & 72 & 72 & Spinoffs & 48 & 48 & 48 & 48 \\
\hline Comparisons & 741 & 741 & 741 & 741 & Comparisons & 538 & 538 & 538 & 538 \\
\hline \multicolumn{5}{|c|}{$t+5$} & \multicolumn{5}{|c|}{$t+6$} \\
\hline & base & $\overline{\text { controls }}$ & count & wProd & & base & controls & count & wProd \\
\hline Spinoff & $\begin{array}{l}.106^{*} \\
(.057)\end{array}$ & $\begin{array}{l}.095 \\
(.068)\end{array}$ & $\begin{array}{c}.110^{* *} \\
(.054)\end{array}$ & $\begin{array}{l}.072 \\
(.050)\end{array}$ & Spinoff & $\begin{array}{c}.212^{* *} \\
(.090)\end{array}$ & $\begin{array}{l}.124 \\
(.121)\end{array}$ & $\begin{array}{l}.127 \\
(.089)\end{array}$ & $\begin{array}{l}.089 \\
(.097)\end{array}$ \\
\hline Spin/Comp Dest. & & & $\begin{array}{c}.023^{* * *} \\
(.004)\end{array}$ & $\begin{array}{c}.021^{* * *} \\
(.004)\end{array}$ & Spin/Comp Dest. & & & $\begin{array}{c}.021^{* *} \\
(.010)\end{array}$ & $\begin{array}{l}.020^{*} \\
(.010)\end{array}$ \\
\hline Parent Initial Dest. ${ }^{a}$ & & & $\begin{array}{c}-5.53 \mathrm{e}-06 \\
(.001)\end{array}$ & $\begin{array}{l}-.002 \\
(.003)\end{array}$ & Parent Initial Dest. ${ }^{a}$ & & & $\begin{array}{c}.041^{* *} \\
(.017)\end{array}$ & $\begin{array}{c}.040^{* *} \\
(.017)\end{array}$ \\
\hline Product overlap ${ }^{b}$ & & & & $\begin{array}{c}.188^{* *} \\
(.076)\end{array}$ & Product overlap ${ }^{b}$ & & & & $\begin{array}{l}.174^{*} \\
(.099)\end{array}$ \\
\hline Const. & $\begin{array}{c}.362^{* * *} \\
(.043)\end{array}$ & $\begin{array}{c}.118^{* *} \\
(.057)\end{array}$ & $\begin{array}{l}-.115 \\
(.082)\end{array}$ & $\begin{array}{c}-.033 \\
(.061)\end{array}$ & Const. & $\begin{array}{c}.319^{* * *} \\
(.069)\end{array}$ & $\begin{array}{l}.600^{* * *} \\
(1.71 \mathrm{e}-15)\end{array}$ & $\begin{array}{c}.526^{* * *} \\
(.033)\end{array}$ & $\begin{array}{c}.529^{* * *} \\
(.033)\end{array}$ \\
\hline Obs & 319 & 319 & 319 & 319 & Obs & 142 & 142 & 142 & 142 \\
\hline $\mathrm{R}^{2}$ & .007 & .422 & .539 & .555 & $\mathrm{R}^{2}$ & .020 & .431 & .520 & .526 \\
\hline Spinoffs & 27 & 27 & 27 & 27 & Spinoffs & 8 & 8 & 8 & 8 \\
\hline Comparisons & 292 & 292 & 292 & 292 & Comparisons & 134 & 134 & 134 & 134 \\
\hline
\end{tabular}

${ }^{a}$ Number of parent export destinations in spinoff entry years.

${ }^{b}$ Spinoff/comparison overlap in year $t+k$ with parent export products in spinoff entry years.

Sources: RAIS 1986-2001 and SECEX 1995-2001.

Notes: Dependent variable is spinoff/comparison overlap in year $t+k$ with parent export destinations in spinoff entry years. Starting with the "controls" column, all columns have 4-digit industry, municipality, and year controls. Standard errors are clustered by spinoff-year. ${ }^{* * *}$ significance at one, ${ }^{* *}$ five, ${ }^{*}$ ten percent levels. 
and sectoral proximity, which are best positioned to catch up by arm's length learning.

We can quantify the spinoff export advantage by comparing the coefficients on the spinoff indicators in Table 5 and Table 7 when all controls are included, which are the smallest coefficients, to the constant terms in the regressions without any controls, which equal the mean overlaps of comparison firms with the parent export destinations in the spinoff entry years. In their entry years spinoffs export to 51 percent $(0.126 / 0.249)$ more parent markets than comparison firms in the same 4-digit industries and municipalities as the parents. This export overlap advantage decreases to 46 percent $(0.136 / 0.297)$ one year later, 33 percent $(0.110 / 0.336)$ two years later, and 21 percent $(0.080 / 0.375)$ three years later.

\section{Spinoffs and Entry Into Adjacent Markets}

The export spillover literature provides evidence that firms tend to export to the same markets as other firms to which they are close either geographically or technologically. Similarly, a newer literature (e.g., Chaney 2014, Morales, Sheu and Zahler 2014) provides evidence that exporting firms tend to use markets they have already entered as a "base" to access other markets that are close, either geographically or by some other metric. The question arises as to whether the exporting firms learned about the other markets after entering the base markets, or whether their entry to the other markets is caused by those markets' similarity to the base markets. This question is similar to ours as to whether spinoffs have an advantage over comparison firms in entering parent markets because of intrafirm learning or because of technological similarity not captured by overlap with parent products. Our placebo test shows that spinoffs have no advantage over comparison firms in entering different parent markets than those already served by their parents when they were founded. This suggests that the spinoff indicator could be a valid and relevant instrument for entry into the base markets in a regression of adjacent market entry on base market entry, because spinoffs have no advantage in entering adjacent markets but have an advantage entering base markets that were served by their parents when the spinoffs were founded.

Following Morales, Sheu and Zahler, we expect firms that export to a base market in a given year to have a higher probability of exporting to adjacent markets in the following year. Morales, Sheu and Zahler define adjacency in four different ways: shared border, shared official language, shared World Bank income group (high income, upper-middle income, lower-middle income, low income), and shared continent. We exclude any destinations that are adjacent to Brazil itself by the definition in use. The source of data for shared border, language, and continent is Mayer and Zignago (2011). We order the adjacency definitions by decreasing probability that firms will enter the adjacent markets, as given by the means of the dependent

variables in Table 8. Our instrumental variable strategy is to use the destination markets served by parents in 
Table 8: OLS Regressions for $t+1$ Export Destinations Adjacent to Parent Export Destinations in Spinoff Entry Years

\begin{tabular}{|c|c|c|c|c|}
\hline & $\begin{array}{c}\text { Contiguous } \\
(1)\end{array}$ & $\begin{array}{c}\text { Language } \\
(2)\end{array}$ & $\frac{\text { Income }}{(3)}$ & $\begin{array}{c}\text { Continent } \\
(4)\end{array}$ \\
\hline Entry Parent Dest. & $\begin{array}{c}.024^{* * *} \\
(.005)\end{array}$ & $\begin{array}{c}.008^{* * *} \\
(.002)\end{array}$ & $\begin{array}{c}.006^{* * *} \\
(.001)\end{array}$ & $\begin{array}{c}.007^{* * *} \\
(.002)\end{array}$ \\
\hline Spin/Comp Destinations & $\begin{array}{c}.003^{* *} \\
(.001)\end{array}$ & $\begin{array}{c}.003^{* * *} \\
(.0008)\end{array}$ & $\begin{array}{c}.002^{* * *} \\
(.0007)\end{array}$ & $\begin{array}{c}.002^{* * *} \\
(.0006)\end{array}$ \\
\hline Parent Destinations & $\begin{array}{c}-.0007^{* * *} \\
(.0002)\end{array}$ & $\begin{array}{c}-.0006^{* * *} \\
(.0002)\end{array}$ & $\begin{array}{c}-.0003^{* * *} \\
(.0001)\end{array}$ & $\begin{array}{c}-.0002^{* * *} \\
(.00007)\end{array}$ \\
\hline Product overlap & $\begin{array}{l}.014 \\
(.009)\end{array}$ & $\begin{array}{l}-.001 \\
(.005)\end{array}$ & $\begin{array}{l}-.002 \\
(.005)\end{array}$ & $\begin{array}{c}-.009^{*} \\
(.005)\end{array}$ \\
\hline $\log$ Size & $\begin{array}{c}.003^{* *} \\
(.001)\end{array}$ & $\begin{array}{l}.002^{* *} \\
(.0007)\end{array}$ & $\begin{array}{l}.0008 \\
(.0007)\end{array}$ & $\begin{array}{l}.001 \\
(.0007)\end{array}$ \\
\hline Observations & 38,820 & 575,506 & 650,460 & 364,618 \\
\hline$R^{2}$ & .059 & .039 & .03 & .029 \\
\hline Mean Dep Var & .016 & .012 & .009 & .007 \\
\hline Spinoffs & 4,105 & 58,221 & 62,827 & 39,337 \\
\hline Comparisons & 34,715 & 517,285 & 587,633 & 325,281 \\
\hline
\end{tabular}

Sources: RAIS 1986-2001 and SECEX 1995-2001.

Notes: The sample universe is all destinations adjacent to parent export destinations in spinoff entry years that are not themselves parent export destinations in the spinoff entry years. Dependent variables are indicators for export in year $t+1$ to each adjacent destination in the sample. Adjacency is defined differently in each column, comprising either destinations that are contiguous, have a common language, have a common income level (by the World Bank's classification for calendar year 1998), or are on a common continent, excluding destinations that are adjacent to Brazil by the respective definition. Entry Parent Dest. is an indicator for export to parent destination in spinoff entry year. All columns have 4-digit industry, municipality, and year controls. Standard errors are clustered by spinoff-year. ${ }^{* * *}$ significance at one, ${ }^{* *}$ five, ${ }^{*}$ ten percent levels.

their spinoffs' entry years as the base markets and use the spinoff indicator as our instrument to predict firm exports to those markets. The idea is that spinoff status predicts entry into parent markets but, conditional on the other controls, is unrelated to entry into adjacent markets.

We begin in Table 8 with OLS regressions of an indicator for firm entry into adjacent markets on an indicator for exports to a parent market the previous year. Except for the spinoff indicator, the control variables used in the fourth columns of Tables 5 to 7 are also included on the right-hand sides of the Table 8 regressions, plus a control for the logarithm of firm size as a proxy for the capability to enter adjacent markets. Exports to a parent market are associated with increased probability of entry into an adjacent market for all four adjacency definitions. The largest coefficient, both absolutely and relative to the mean of the dependent variable, is for the shared border adjacency definition: exports to a parent market are associated with a 2.4 percentage point increase in the probability of entry into a market that borders on the parent market, compared to a 1.6 percent mean probability.

Table 9 shows the first-stage regressions, with the indicator for entry into a parent market as the de- 
Table 9: First Stage of IV Regressions for Adjacent Export Destinations

\begin{tabular}{|c|c|c|c|c|}
\hline & $\begin{array}{c}\text { Contiguous } \\
(1)\end{array}$ & $\begin{array}{c}\text { Language } \\
(2)\end{array}$ & $\begin{array}{c}\text { Income } \\
(3)\end{array}$ & $\begin{array}{c}\text { Continent } \\
(4)\end{array}$ \\
\hline Spinoff & $\begin{array}{c}.052^{* * *} \\
(.015)\end{array}$ & $\begin{array}{c}.034^{* * *} \\
(.012)\end{array}$ & $\begin{array}{c}.043^{* * *} \\
(.011)\end{array}$ & $\begin{array}{c}.037^{* * *} \\
(.014)\end{array}$ \\
\hline Spin/Comp Destinations & $\begin{array}{c}.018^{* * *} \\
(.002)\end{array}$ & $\begin{array}{c}.023^{* * *} \\
(.003)\end{array}$ & $\begin{array}{c}.02^{* * *} \\
(.002)\end{array}$ & $\begin{array}{c}.017^{* * *} \\
(.002)\end{array}$ \\
\hline Parent Destinations & $\begin{array}{c}-.005^{* * *} \\
(.0008)\end{array}$ & $\begin{array}{c}-.006^{* * *} \\
(.001)\end{array}$ & $\begin{array}{c}-.003^{* * *} \\
(.0007)\end{array}$ & $\begin{array}{c}-.001^{* *} \\
(.0005)\end{array}$ \\
\hline Product overlap & $\begin{array}{c}.191^{* * *} \\
(.038)\end{array}$ & $\begin{array}{c}.231^{* * *} \\
(.032)\end{array}$ & $\begin{array}{c}.204^{* * *} \\
(.027)\end{array}$ & $\begin{array}{c}.193^{* * *} \\
(.03)\end{array}$ \\
\hline $\log$ Size & $\begin{array}{l}.006^{*} \\
(.004)\end{array}$ & $\begin{array}{c}.008^{* * *} \\
(.003)\end{array}$ & $\begin{array}{c}.007^{* * *} \\
(.002)\end{array}$ & $\begin{array}{c}.00009 \\
(.002)\end{array}$ \\
\hline Observations & 38,820 & 575,506 & 650,460 & 364,618 \\
\hline$R^{2}$ & .218 & .206 & .224 & .264 \\
\hline Spinoffs & 4,105 & 58,221 & 62,827 & 39,337 \\
\hline Comparisons & 34,715 & 517,285 & 587,633 & 325,281 \\
\hline K-P F-test (weak id) & 11.694 & 7.787 & 13.959 & 7.311 \\
\hline
\end{tabular}

Sources: RAIS 1986-2001 and SECEX 1995-2001.

Notes: Dependent variables are indicators for export to parent destinations in spinoff entry years, where the parent destinations are adjacent to at least one other country that is not a parent export destination. Adjacency is defined differently in each column, comprising either destinations that are contiguous, have a common language, have a common income level (by the World Bank's classification for calendar year 1998), or are on a common continent, excluding destinations that are adjacent to Brazil by the respective definition. All columns have 4-digit industry, municipality, and year controls. Standard errors are clustered by spinoffyear. ${ }^{* * *}$ significance at one, ${ }^{* *}$ five, ${ }^{*}$ ten percent levels.

pendent variable. As expected, the spinoff indicator is a strong predictor of entry into any individual parent market, just as it is a strong predictor of overlap with all parent markets. Table 10 shows the second-stage results. For all four adjacency definitions, the coefficient on the parent market entry indicator loses statistical significance, though for the shared language and shared continent adjacency definitions the KleinbergenPapp $F$-tests in Table 9 indicate weak instruments under conventional Stock and Yogo (2005) criteria. ${ }^{14}$ The negative signs could indicate that entries into the parent markets absorb the productive capacities of the entering firms, making it less likely that they can enter other markets in the following year. The negative coefficients are statistically significant for the larger firm samples (see Online Supplement).

Overall, Table 10 does not support the hypothesis that exports to a country promote exports to "adjacent" countries in the following year. Instead, the loss of statistical significance of the indicator for entry into the parent market (in Table 10) using spinoff status as the instrumental variable, compared to Table 8 using OLS, suggests that a firm's supply-side characteristics rather than its knowledge of the base market determine

\footnotetext{
${ }^{14}$ If we choose a power of 0.15 for our $F$-test of size 0.05 , for example, our single instrument for a single endogenous regressor requires a critical value of 8.96 or higher.
} 
Table 10: IV Regressions for $t+1$ Export Destinations Adjacent to Parent Export Destinations in Spinoff Entry Years

\begin{tabular}{|c|c|c|c|c|}
\hline & $\begin{array}{c}\text { Contiguous } \\
(1)\end{array}$ & $\begin{array}{c}\text { Language } \\
(2)\end{array}$ & $\begin{array}{c}\text { Income } \\
(3)\end{array}$ & $\frac{\text { Continent }}{(4)}$ \\
\hline Entry Parent Dest. & $\begin{array}{c}-.116 \\
(.09)\end{array}$ & $\begin{array}{c}-.034 \\
(.069)\end{array}$ & $\begin{array}{l}-.083 \\
(.055)\end{array}$ & $\begin{array}{c}-.053 \\
(.067)\end{array}$ \\
\hline Spin/Comp Destinations & $\begin{array}{c}.005^{* * *} \\
(.002)\end{array}$ & $\begin{array}{c}.004^{* *} \\
(.001)\end{array}$ & $\begin{array}{c}.004^{* * *} \\
(.001)\end{array}$ & $\begin{array}{c}.003^{* *} \\
(.001)\end{array}$ \\
\hline Parent Destinations & $\begin{array}{c}-.001^{* *} \\
(.0005)\end{array}$ & $\begin{array}{c}-.0009^{*} \\
(.0005)\end{array}$ & $\begin{array}{c}-.0006^{* * *} \\
(.0002)\end{array}$ & $\begin{array}{c}-.0003^{* *} \\
(.0001)\end{array}$ \\
\hline Product overlap & $\begin{array}{l}.044^{*} \\
(.023)\end{array}$ & $\begin{array}{l}.009 \\
(.017)\end{array}$ & $\begin{array}{l}.018 \\
(.013)\end{array}$ & $\begin{array}{l}.004 \\
(.014)\end{array}$ \\
\hline $\log$ Size & $\begin{array}{c}.004^{* *} \\
(.002)\end{array}$ & $\begin{array}{c}.002^{* *} \\
(.001)\end{array}$ & $\begin{array}{l}.001 \\
(.001)\end{array}$ & $\begin{array}{l}.0009 \\
(.0007)\end{array}$ \\
\hline Observations & 38,820 & 575,506 & 650,460 & 364,618 \\
\hline Mean Dep Var & .016 & .012 & .009 & .007 \\
\hline Spinoffs & 4,105 & 58,221 & 62,827 & 39,337 \\
\hline Comparisons & 34,715 & 517,285 & 587,633 & 325,281 \\
\hline
\end{tabular}

Sources: RAIS 1986-2001 and SECEX 1995-2001.

Notes: The sample universe is all destinations adjacent to parent export destinations in spinoff entry years that are not themselves parent export destinations in the spinoff entry years. Dependent variables are indicators for export in year $t+1$ to each adjacent destination in the sample. Adjacency is defined differently in each column, comprising either destinations that are contiguous, have a common language, have a common income level (by the World Bank's classification for calendar year 1998), or are on a common continent, excluding destinations that are adjacent to Brazil by the respective definition. Entry Parent Dest. is instrumented by spinoff status. All columns have 4-digit industry, municipality, and year controls. Standard errors are clustered by spinoff-year. Standard errors are clustered by spinoff-year. ${ }^{* * *}$ significance at one, ${ }^{* *}$ five, ${ }^{*}$ ten percent levels.

expansions to adjacent markets. We should note that our predictor of exports to the base country is employee spinoffs, which are capitalizing on intrafirm learning. Learning about adjacent markets would occur through a different process. It is possible the employee spinoffs are less well suited to benefit from that process than other firms.

\section{Conclusions}

It is well established that employee spinoffs learn their parents' technologies, but little is known about their demand-side learning. We exploit the identification in international trade data of parent markets (countries) to investigate whether exporting employee spinoffs of exporting parents have an advantage in accessing their parents' markets over exporting comparison firms well positioned to learn those markets at arm's length. We find that, controlling for the greater overlap of spinoffs with their parents' export products, at entry spinoffs access 51 percent more parent markets than exporting firms in the same 4-digit industries and municipalities as the parents. This advantage shrinks monotonically with time, losing statistical significance at conventional 
levels four years after entry, which indicates that intrafirm learning provides spinoffs with a four-year head start over arm's-length learning. Spinoffs do not overlap more than comparison firms with parent markets that the parents did not serve at spinoff entry, providing evidence against the alternative hypothesis that product overlap inadequately controls for greater technological similarity of spinoffs to parents. Our results suggest that intrafirm learning about parent markets may contribute to superior spinoff performance relative to startups without parents.

A broader message of this paper is that international trade data can be useful in understanding how a firm accumulates a customer base. Our results imply that one method is for the firm founders to establish relationships with customers and knowledge of market idiosyncracies prior to startup. The duration of buyersupplier (importer-exporter) relationships in international trade (Monarch and Schmidt-Eisenlohr 2016) can provide still more insight into the dynamics of firm demand. At the same time, better knowledge of how firms acquire customers can improve our understanding of the behavior of international trade at the aggregate level. Information spillovers within and between firms both contribute to more "sticky" aggregate exports in which countries tend to increase exports to markets they have already entered rather than try new markets. Quantifying the relative contributions of intra- and inter-firm learning to export stickiness in a structural model is a good subject for future research. 


\section{References}

Aitken, Brian, Gordon H. Hanson, and Ann E. Harrison. 1997. "Spillovers, Foreign Investment, and Export Behavior." Journal of International Economics, 43(1-2): 103-132.

Albornoz, Facundo, Hector F. Calvo-Pardo, Gregory Corcos, and Emanuel Ornelas. 2012. "Sequential Exporting." Journal of International Economics, 88(1): 17-31.

Bastos, Paulo, and Joana Silva. 2012. "Networks, Firms, and Trade." Journal of International Economics, 87(2): 352-64.

Bernard, Andrew B., Emmanuel Dhyne, Glenn C. G. Magerman, Kalina Manova, and Andreas Moxnes. 2017. "The Origins of Firm Heterogeneity: A Production Network Approach.” Tuck School of Business at Dartmouth, unpublished manuscript.

Chaney, Thomas. 2014. “The Network Structure of International Trade.” American Economic Review, 104(11): 36003634.

Eaton, Jonathan, Marcela Eslava, C. J. Krizan, Maurice Kugler, and James R. Tybout. 2014. "A Search and Learning Model of Export Dynamics." Society for Economic Dynamics, 2015 Meeting Papers number 1535.

Eriksson, Tor, and Johan Moritz Kuhn. 2006. "Firm Spin-Offs in Denmark 1981-2000: Patterns of Entry and Exit." International Journal of Industrial Organization, 24(5): 1021-1040.

Fernandes, Ana P., and Heiwai Tang. 2014. "Learning to Export from Neighbors." Journal of International Economics, 94(1): 67-84.

Fitzgerald, Doireann, Stefanie Haller, and Yaniv Yedid-Levi. 2016. "How Exporters Grow.” NBER Working Paper, 21935.

Foster, Lucia, John Haltiwanger, and Chad Syverson. 2008. "Reallocation, Firm Turnover, and Efficiency: Selection on Productivity or Profitability?" American Economic Review, 98(1): 394-425.

Foster, Lucia, John Haltiwanger, and Chad Syverson. 2016. "The Slow Growth of New Plants: Learning about Demand?" Economica, 83(329): 91-129.

Franco, April Mitchell, and Darren Filson. 2006. "Spin-Outs: Knowledge Diffusion through Employee Mobility." RAND Journal of Economics, 37(4): 841-860.

Gourio, Francois, and Leena Rudanko. 2014. “Customer Capital.” Review of Economic Studies, 81(3): 1102-36.

Greenaway, David, Nuno Sousa, and Katharine Wakelin. 2004. "Do Domestic Firms Learn to Export from Multinationals?" European Journal of Political Economy, 20(4): 1027-1043. 
Hvide, Hans K. 2009. “The Quality of Entrepreneurs.” Economic Journal, 119(539): 1010-1035.

Jovanovic, Boyan. 1979. "Job Matching and the Theory of Turnover." Journal of Political Economy, 87(5): 972-990.

Kee, Hiau Looi, and Kala Krishna. 2008. "Firm-Level Heterogeneous Productivity and Demand Shocks: Evidence from Bangladesh.” American Economic Review, 98(2): 457-62.

Klepper, Steven, and Sally Sleeper. 2005. "Entry by Spinoffs.” Management Science, 51(8): 1291-1306.

Koenig, Pamina, Florian Mayneris, and Sandra Poncet. 2010. "Local Export Spillovers in France." European Economic Review, 54(4): 622-41.

Labanca, Claudio, Danielken Molina, and Marc-Andreas Muendler. 2014. "Preparing to Export." University of California, San Diego, unpublished manuscript (earlier version NBER Working Paper, 18962).

Mayer, Thierry, and Soledad Zignago. 2011. "Notes on CEPII's Distances Measures: The GeoDist database." CEPII Working Paper, 2011-25.

Mion, Giordano, and Luca David Opromolla. 2014. “Managers' Mobility, Trade Performance, and Wages." Journal of International Economics, 94(1): 85-101.

Monarch, Ryan, and Tim Schmidt-Eisenlohr. 2016. "Learning and the Value of Relationships in International Trade." CESifo Working Paper, 5724.

Morales, Eduardo, Gloria Sheu, and Andrés Zahler. 2014. "Gravity and Extended Gravity: Using Moment Inequalities to Estimate a Model of Export Entry.” NBER Working Paper, 19916.

Muendler, Marc-Andreas, James E. Rauch, and Oana Tocoian. 2012. "Employee Spinoffs and Other Entrants: Stylized Facts from Brazil.” International Journal of Industrial Organization, 30(5): 447-458.

Phillips, Damon J. 2002. "A Genealogical Approach to Organizational Life or Chances: The Parent-progeny Transfer Among Silicon Valley Law Firms, 1946-1996.” Administrative Science Quarterly, 47(3): 474-506.

Stock, James H., and Motohiro Yogo. 2005. “Testing for Weak Instruments in Linear IV Regression.” In Identification and Inference for Econometric Models: Essays in Honor of Thomas Rothenberg., ed. Donald W. K. Andrews and James H. Stock, Chapter 5, 80-108. Cambridge and New York:Cambridge University Press.

Timoshenko, Olga A. 2015a. "Learning versus Sunk Costs Explanations of Export Persistence." European Economic Review, 79(0): 113-28.

Timoshenko, Olga A. 2015b. "Product Switching in a Model of Learning." Journal of International Economics, 95(2): 233-49. 


\section{Appendix}

\section{The Impact of Spinoff “Treatment” on Destination Overlap}

In the text we compared the destination overlap between spinoff firms and their parent firms to the destination overlap of other firms that are well positioned to learn about parent markets at arm's length, motivated by findings in the literature. Those comparison firms were in the same 4-digit industry and municipality as the parent firms. In this Appendix we take a different approach: we find matches for the spinoff firms, and then ask if spinoff treatment yields greater overlap with parent destinations compared to other firms that might learn from the same parent.

Concretely, we now estimate the effect of being a spinoff on a firm's overlap with parent destinations using a propensity score matching technique of spinoffs to other firms that are like spinoffs in the relevant characteristics. To stay close in spirit to our approach in the text, we require the control firms for propensity score matching to share the characteristic with comparison firms in the text that they are also exporters in the year of spinoff entry. However, we want the control firms now to share the industry of the spinoff rather than the parent. Table A1 shows that if we restrict our sample of control firms to those that export in the spinoff entry year and are in the same 4-digit industry as the spinoff, we cover all but four of 417 parent firms and all but five of 446 spinoff firms. We do not restrict our comparison firms to new firms, so as to capture all firms that may learn at arm's length from the parent firms as in the text.

Control firms are not naturally paired with any particular parent firm. We therefore build the sample of potential control firms by exhausting every possible pairing between a control firm and the spinoffs' 413 parents, all of which become a control firm's potential pseudo-parents. In the matching process, however, we restrict a match between a spinoff and a control firm to be a "hard match" such that the spinoff's parent is also the only permissible pseudo-parent of the control firm (excluding the possibility that a match between a spinoff and a control firm would involve a spinoff parent that differs from the control firm's pseudo-parent). To mitigate the risk of bad matches between spinoffs and unrelated control firms, we adopt radius matching with a customary caliper of 0.01 of the propensity score.

Table 5 in the text showed three more characteristics on which we can match control firms to spinoffs: the number of destinations to which the firm exports, the number of destinations to which the spinoff's parent (the control firm's pseudo-parent) exports, and the product overlap with a spinoff's parent (the control firm's pseudo-parent). To those variables we are able to add the logarithm of distance to the spinoff's parent (the control firm's pseudo-parent) and the logarithm of firm size measured by number of employees. Distance from a spinoff or control firm to a spinoff's parent (a control firm's pseudo-parent) is measured 


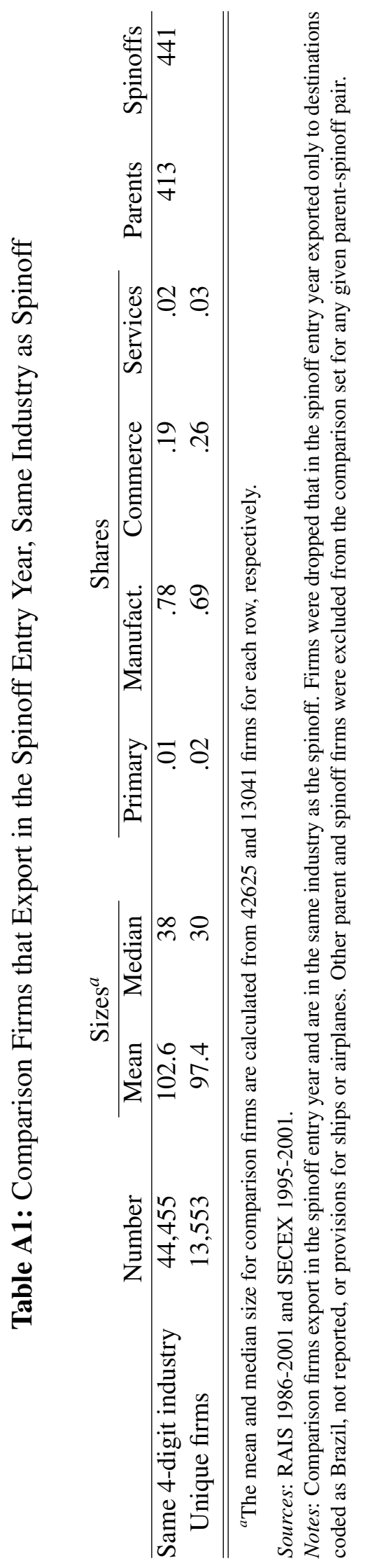


Table A2: Propensity Score Match Covariate Balance for Logit Specification

\begin{tabular}{|c|c|c|c|c|c|}
\hline \multirow[b]{2}{*}{ Variable } & \multicolumn{2}{|c|}{ Mean } & \multirow[b]{2}{*}{$\%$ Bias } & \multicolumn{2}{|c|}{$t$-test } \\
\hline & Treated & Control & & $t$ & $p>|t|$ \\
\hline Spin/Comp Dest. & 3.188 & 3.449 & -5.4 & -0.49 & 0.626 \\
\hline Parent Dest. & 12.642 & 12.642 & 0.0 & -0.00 & 1.000 \\
\hline Prod Overlap & .190 & .164 & 8.6 & 0.87 & 0.385 \\
\hline log Size & 3.238 & 3.455 & -14.0 & -1.22 & 0.224 \\
\hline Diff. Muni & .6364 & .631 & 1.5 & 0.11 & 0.912 \\
\hline log Dist. & 3.067 & 3.145 & -3.5 & -0.27 & 0.786 \\
\hline
\end{tabular}

Sources: RAIS 1986-2001 and SECEX 1995-2001.

by kilometers from the firm's municipality to the parent's municipality, computed using coordinates for the political centers of the municipalities supplied by the Brazilian statistical agency Instituto Brasileiro de Geografia e Estatística. If the spinoff or control firm and the (pseudo-)parent firm are in the same municipality, distance between them is zero. We cannot take the logarithm of zero, so we create an indicator variable that takes the value of one when the spinoff or control firm is in a different municipality from the (pseudo-)parent and zero otherwise, and interact it with the logarithm of distance. We then use both the different municipality indicator and its interaction with the logarithm of distance to match control firms to spinoffs. Although we have data on firm age, we cannot use this variable in our propensity score matching estimation because all spinoffs are age zero by construction, making it impossible to achieve covariate balance if this variable were included.

To obtain propensity scores for matches of spinoffs and control firms, we first estimate a logit model of the probability that a firm is a spinoff. Unfortunately, we were unable to include the fixed effects used in Table 5 in our propensity score estimation with the logit model. The dimensionality of these fixed effects was larger than the logit estimation routine could handle under manageable convergence criteria. ${ }^{15}$ We restrict our sample to observations that have a common support, by dropping all observations from the spinoff-firm and control-firm groups if they have a propensity score that is smaller than the minimum or larger than the maximum in the respective other group. Table A2 documents that we achieve covariate balance when using logit to estimate propensity scores. Only 176 of the 441 spinoffs remain in the treatment group under this procedure.

To enlarge the number of spinoffs included in the treatment group, and to gauge the possible impact of omitting the fixed effects from the propensity score estimation, we also use a linear probability model, without and with the fixed effects, to estimate propensity scores. Without fixed effects, 360 of the 441

\footnotetext{
${ }^{15}$ A conditional logit model could accommodate large numbers of fixed effects in estimation but its propensity scores would be conditional on unknown fixed effects and hence not offer an improvement.
} 
Table A3: Propensity Score Match Treatment Effect Estimates

\begin{tabular}{|c|c|c|c|}
\hline & $\frac{\text { Logit }}{(1)}$ & $\frac{\text { LPM }}{(2)}$ & $\begin{array}{c}\text { LPM with FE } \\
\text { (3) }\end{array}$ \\
\hline ATT & $\begin{array}{c}0.077^{* *} \\
(0.031)\end{array}$ & $\begin{array}{c}0.133^{* * *} \\
(0.026)\end{array}$ & $\begin{array}{c}0.125^{* * *} \\
(0.029)\end{array}$ \\
\hline Fixed effects & No & No & Yes \\
\hline Observations (on common support) & 7,157 & 21,139 & 4,865 \\
\hline Treated & 176 & 360 & 204 \\
\hline Controls & 6,981 & 20,779 & 4,661 \\
\hline
\end{tabular}

Sources: RAIS 1986-2001 and SECEX 1995-2001.

Notes: ${ }^{* * *}$ significance at one, ${ }^{* *}$ five, ${ }^{*}$ ten percent levels.

spinoffs remain in the treatment group; with fixed effects 204 remain. Unfortunately, we do not achieve covariate balance in either case.

Table A3 reports estimates of the average effect of treatment on the treated (ATT) for our three propensityscore estimates, using logit to estimate propensity scores in the first column, a linear probability model without fixed effects in the second column and with the industry, municipality, and year fixed effects (as in Table 5) in the third column. The ATT shows the effect of spinoff treatment on overlap with parent destinations (estimates in the text are for the ATT so we restrict our attention to the ATT here). A comparison of the third column to the second shows that the ATT is little affected by the inclusion of the fixed effects. In the first column the ATT is about one-third smaller than the coefficient on the spinoff indicator in the last column of Table 5 in the text.

The text results and the results in this appendix are mutually supportive. We find employee spinoffs to have an economically and statistically significantly greater overlap with the destinations of their parent firms regardless of identification strategy. It is difficult to compare the economic magnitudes given the different samples of spinoffs selected by the two procedures. 